\title{
Journeys in Language Education
}

This issue of ELOPE is dedicated to language education, which is gaining significance in today's world as many countries are reshaping their language policies by either introducing languages earlier in the curriculum or implementing additional languages into primary and secondary education. In this context many issues need to be reconsidered, among which teaching and teacher education are the most crucial ones.

The title of this volume is related to journeys. Language education involves many different types of them. The first journey is that of the discipline of language education itself. It has come a long way from its first beginnings, always evolving and always trying to find the magic formula for the most effective way of teaching. As a result, many teaching approaches and methods have been developed and tried out (some with more success, others with less) and a variety of contextual factors that best support language learning have been discussed along the way.

The second journey signifies the personal development of each teacher, starting from a novice teacher still trying to figure out how to find their way in the classroom (and staffroom) to a more confident and autonomous teacher, trusting themselves and their choices in teaching. Teachers spend many hours on this journey, exploring what works best for their learners, learning from mistakes and celebrating small victories. Many of them come to the conclusion that Durant's saying "we teach more by what we are than by what we teach" holds true in many teaching contexts.

The third journey is the journey of a language learner. They are the ones who are the most influenced by the changes in educational policies, the development of new methods and the choices that teachers make in their classrooms. If they are lucky, they live in a society that encourages language education and appreciates its teachers, investing in learning and teacher education.

Last but not least, journeys can be related to the teaching and teacher development that happen in countries that are part of this ELOPE issue. Among them one can find Croatia, Nigeria, Poland, Slovenia and Kosovo. Despite different contexts, the authors are all united in the wish to contribute to the quality of teaching in their respective countries.

The article "The Use of Speaking Strategies by Pre-Service EFL Teachers" written by Jelena Filipović, Alenka Mikulec and Ivana Cindrić begins the journey in the language teaching section. The authors claim that speaking is a skill that prevails within communicative competence, and that language teachers should have a high degree of speaking fluency and accuracy and be familiar with a variety of speaking strategies. They examine pre-service EFL teachers' perceived use of speaking strategies and their relation to their EFL and speaking proficiency.

The second article, "ESL Teachers and Diagnostic Assessment: Perceptions and Practices" by Folasade Esther Jimola and Graceful Onovughe Ofodu, discusses teachers' perceptions towards and the use of diagnostic assessment in language classrooms, noting that EFL teachers 
that took part in the study had inaccurate perceptions of the purpose of diagnostic assessment and negative attitudes towards it. The authors suggest that the most important factors that influence assessment practices are schooling, professional coursework and teaching context, thus summarizing the decisive elements in language education.

Polona Lilić and Silva Bratožs paper "The Effectiveness of Using Games for Developing Young Learners' Grammar Competence" brings to light the teaching of grammar through the use of games. Games can be employed in teaching all language skills and features, particularly when it comes to teaching young learners. The results of an experimental study presented in the article prove that using games in teaching grammar is more efficient than adopting traditional ELT activities. The authors sum up the article by writing that games take into account learners' needs and preferences and are a natural way of learning for young learners.

In "A Comparative Study of CLIL Trajectories in the Polish Education System" Piotr Romanowski presents different CLIL models used by Polish teachers. The article discusses CLIL provision or, as it is labelled in Poland, bilingual education. The research shows its use is most common in bigger cities and, not surprisingly, English is the most popular language used as a medium of instruction. The content subjects which are taught in a foreign language are Maths, Physics and Geography in lower secondary schools, and besides Maths and Physics, Chemistry is the third most common content subject used for CLIL instruction in uppersecondary schools. The author concludes that CLIL provision in Poland still needs thorough improvements, among them unification of the curricula and the amount of exposure to a foreign language.

The final article in the ELT section, "Teachers' Perceptions of Developing Writing Skills in the EFL Classroom" by Lisjeta Thaqi Jashari and Mateja Dagarin Fojkar, addresses the issue of developing learners' writing skills, which is still perceived as the most difficult task for many learners. The surveyed teachers stated that writing is an essential language skill, although they did not practise it as much as the other skills. The authors suggest different actions to remedy the situation, among which differentiated instruction and the introduction of a variety of teaching strategies to teachers might improve not only learners' writing skills but also their language competence in general.

In the language section, Sanja Škifić and Anita Pavić Pintarić in their contribution titled "Tracing the Space Between Euphemisms and Dysphemisms: The Case of Obesity in English and German", focus on how obesity is represented in English and German. By using a corpus of expressions from different lexicographic sources, the authors analysed their descriptions in dictionaries. Furthermore, they conducted a survey among native speakers of German and English examining to what extent lexicographic descriptions match the native speakers' perceptions of euphemisms.

The literature section concludes this volume with Nejc Rožman Ivančičss paper on "The Image of a Woman of Colour and Native American Woman in Two Kerouac's Novels: A Double Otherness". The author examines the portrayal of a Native American woman and a woman of colour in two of Kerouac's novels, and discusses Kerouac's attitude towards women 
and non-white ethnicities. He sums up his analysis by stating that the male protagonist in the novels uses female characters only as objects for his own self-discovery, revealing his racial prejudice.

The focus of this volume of ELOPE has been on language learning and teaching. Hopefully, this issue will open the door to more journeys within language education. Further research in this area should lead to better teaching practices and well-educated teachers who will contribute to the quality of education and progress of pupils and, as they grow up, confident users of languages. Let me finish with the words of an inspiring American writer:

I have come to believe that a great teacher is a great artist and that there are as few as there are any other great artists. Teaching might even be the greatest of the arts since the medium is the human mind and spirit. (John Steinbeck)

Mateja Dagarin Fojkar, University of Ljubljana, Slovenia

Guest Editor of ELOPE Vol. 16, No. 2 (2019) 